\title{
Analysis pours cold water on flood theory
}

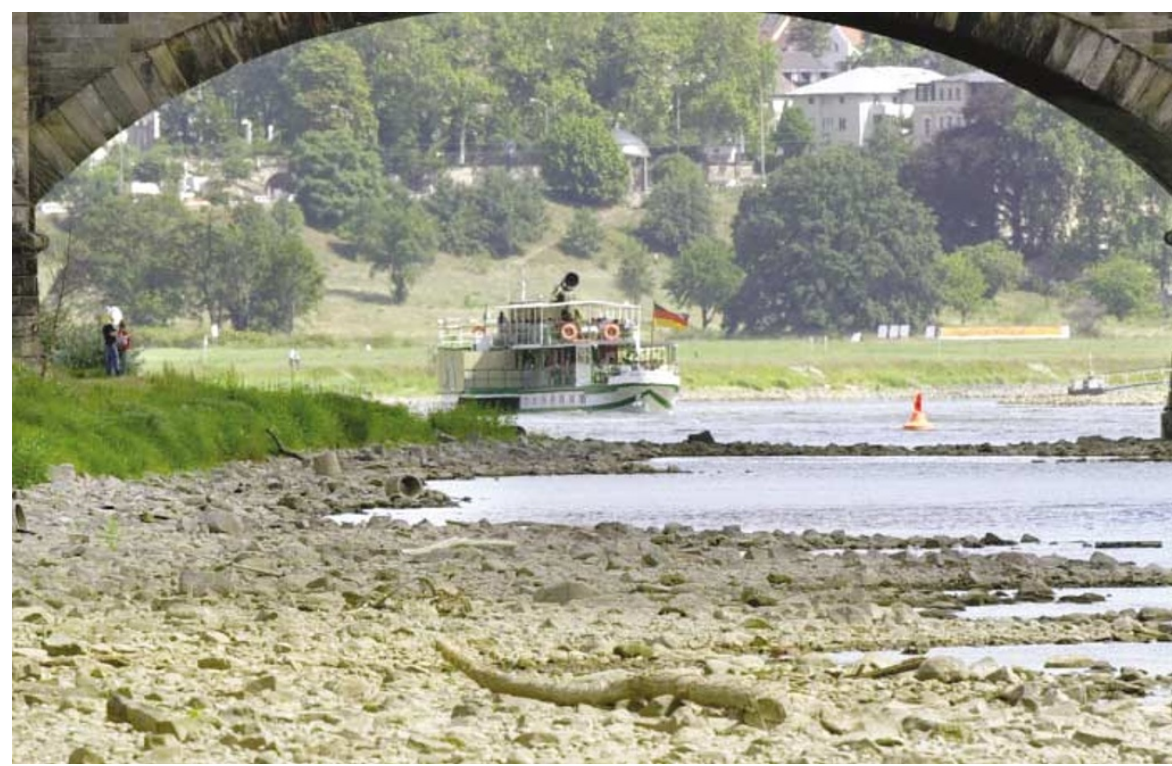

Trend free? This year's low water levels are in stark contrast to last summer's floods on the Elbe.

\section{Quirin Schiermeier, Munich}

Last summer's flooding around the River Elbe and its tributaries was one of central Europe's biggest natural disasters in living memory, and some observers saw it as part of a trend towards more extreme weather. But according to a comprehensive analysis by German climate researchers, there is no evidence that this is so (see page 166).

The researchers' statistical analysis of recent river-flow data and historical records shows no upward trend in the frequency of extreme summertime flooding in eastern Germany, Poland and the Czech Republic.

Records tapped by the analysis include the Weikinn archive, a bank of more than 20,000 documents on floods and rainfall dating back to the eleventh century. The archive - compiled by the late Curt Weikinn, a selftaught climatologist from the former East Germany - has often been ignored because of the archivist's unsystematic approach. But, the fresh analysis finds, a comparison with other climate records suggests that the archive's flood data are very reliable.

The analysis finds that changes in temperature over the past 1,000 years have affected hydrology in the region, but winter flooding actually decreased over the past century, and summer flooding shows no trend.

"According to the records, the Elbe flood last year was indeed a centennial event, with an average return period of 168 years," says Manfred Mudelsee, a hydrologist at the University of Leipzig, and the paper's lead author. "We had almost finished our analysis when the flood came, and we decided to include it. But it would be frivolous to derive from this single event any kind of statistical trend for the past 50,100 or 150 years," he says.

Analysis of historic sources is worthwhile and instructive in climate research, provided that the findings are interpreted with due caution, says Axel Bronstert, a hydrologist and flood expert at the University of Potsdam in Germany. But he warns against interpreting the findings as an indication that flood occurrence won't increase in the future.

"The absence of an upward trend might appear reassuring," he says, "but it isn't." At least one high-resolution climate model suggests that, on the contrary, summertime flooding in Europe may become more frequent under the influence of greenhousegas-induced global warming, even though continental summers are becoming drier (J. H. Christensen and O. B. Christensen Nature 421, 805-806; 2003). The latest findings don't disprove these predictions, Bronstert says.

According to the insurance company Munich Re, the Elbe flood caused US\$18.5 billion in damage. In the wake of the flood, Germany and the Czech Republic agreed on a cross-border action plan to improve flood warning and protection systems.

The plan, which includes the creation of larger flood plains to buffer peak flows, remains necessary, says Christian Korndörfer, head of the environmental office of Dresden, the city worst hit by the flood. "Whether or not you can make out a trend, the Elbe last year showed us what is possible, and we will have to take appropriate precautions," he says.

Flood managers take into account how climate change may affect precipitation and runoff, says Otto Malek, a flood-protection expert at the German federal environment ministry. But given the risks and prevailing uncertainties, it would be negligent to delay concrete actions until we have more robust trends, he adds.

"The real problem is that there are too many people building houses, and amassing material assets, in areas known to be in danger of flooding," Malek says.

\section{Ministers appointed to engineer revival in Iraqi research}

\section{Geoff Brumfiel, Washington}

The rebuilding of Iraq's scientific infrastructure stepped up a gear last week with the establishment of a research ministry.

Iraq's chief civilian administrator, US diplomat Paul Bremer, announced on 1 September that the US-led coalition occupying Iraq had abolished the Ministry of Atomic Energy and set up a Ministry of Science and Technology in its place. The new ministry features six directorates dealing with energy, the environment, information technology, agriculture, materials science and industrial development. It will be led by
Rashad Omar Mandan, a British-trained civil engineer who served at the Iraqi oil ministry until he fled the country in 1999.

Mandan was sworn in as minister of science and technology on 2 September along with Iraq's first minister of higher education, Ziad Abderrazzak Mohammad Aswad, a US-trained engineer who previously headed the oil-engineering department at Baghdad University.

The US government has also named John Agresto, former president of St John's College in Sante Fe, New Mexico, as the senior American official who will oversee Iraq's university system. "From what I gather, the situation is very bad - but not desperate," Agresto says. He adds that his priorities will be to rebuild the infrastructure of the colleges and hire faculty members who were dismissed or exiled under former Iraqi president Saddam Hussein.

Agresto, a political scientist, was deputy head of the National Endowment for the Humanities under President Ronald Reagan. During his tenure at St John's College, he got to know Donald Rumsfeld, the US defence secretary, whose wife sat on the college's board of trustees. 